\title{
Grain Legumes Production in Ethiopia: A Review of Adoption, Opportunities, Constraints and Emphases for Future Interventions
}

\author{
Erana Kebede ${ }^{1, \mathrm{a}, *}$ \\ ${ }^{I}$ School of Plant Sciences, College of Agriculture and Environmental Sciences, Haramaya University, Ethiopia
} *Corresponding author

A R T I C L E I N F O A B S T R A C T

Review Article

Accelerating agricultural growth remains one of the most urgent goal of Ethiopia as the agricultural sector is the backbone of the Ethiopian economy. The adoption of new agricultural technologies and improved practices are particularly important in increasing agricultural production. This comprises strengthening legumes adoption and production as it contributes to better food security and more

Received : 12/12/2019 sustainable farming systems. Grain legumes are necessary elements of crop production in Ethiopia. The adoption and use of legume crops have been advocated for enhanced nutrition and preserving soil resources. Different improved varieties and legume production technologies have been made available to farmers through various sectors and projects in the country. Various policy measures and initiatives have also been made in improving the adoption, technology generation and contribution of legumes to the various system. Despite their contribution and considerable initiatives, over-all

Keywords: Adoption Agricultural technology

Food security Grain legumes

Productivity level of adoption and use of legume production is still low. A wide array of technical, economic, social, and institutional factors has been found to encounter the adoption, use and production of legumes along with their value-chain. However, there are still various opportunities that different grain legumes are to be adopted and promoted to increase production and productivity. Essential interventions, innovative approaches, increased production packages and improved technologies and market access should be emphasized and integrated to strengthen grain legumes adoption and production.

eranak.neda@gmail.com

(iD) https://orcid.org/0000-0002-3584-6757|

This work is licensed under Creative Commons Attribution 4.0 International License

\section{Introduction}

Ethiopian economy is fundamentally agrarian where the performance of the agriculture sector dictates the entire economic performance of the country. Despite the reportedly growing importance of the manufacturing and the industry sectors, agriculture accounts for nearly $46 \%$ of the gross-domestic product (GDP), $73 \%$ of labor employment and $80 \%$ of foreign export earnings (Yirga, 2010; Degaga and Angasu, 2017). Ethiopian export commodities are almost entirely dominated by agricultural commodities that account for, on average, $75 \%$ of the total export earnings of the country. Among the agricultural commodity, coffee is the largest foreign exchange earner and legumes are estimated to be the third most important export crop in Ethiopia next to sesame (Kebede, 2020).

The population of Ethiopia undergo the rapid growth and expected to double by the year 2050 compared with 2010 while the GDP is expected to show a considerable increase from below USD 700 to above USD 5500 within the range of 2015 to 2050 year (UNPF, 2017; van Loon et al, 2018). Along these lines, raising production levels and decreasing their inconstancy are fundamental parts of enhancing nutrition security in Ethiopia, both to help guarantee sufficient food accessibility and to increase family unit wages (IFPRI, 2011).

Feeding these rapidly growing populations by means of extensive farming is becoming unattainable due to the high demand for food and limited opportunities for area expansion (Agazhi, 2016). Hence, agricultural research and technological improvements are crucial to increase agricultural productivity to meet the demand for food and thereby reduce poverty (Asfaw et al., 2011). These technologies include new agricultural practices such as integration of legume crops in the farming systems, adoption of high-yielding varieties and associated products such as crop insurance that have the potential to contribute to economic growth and poverty reduction (Habtewold, 2018). A large-scale adoption and dissemination of these new technologies are very essential to raise agricultural production and productivity, raise income, reduce poverty and to enhance the food security and children's nutrition, on a sustainable basis (Tsegaye and Bekele, 2012; Degye et al., 2013). 
Among the crops produced in Ethiopia, grain legumes contribute a major way towards poverty reduction, improving food security, improving nutrition and health and sustaining the natural resource base. Despite their contribution in different aspects, the adoption and use of legume technologies have still remained negligible and limited (Ferede et al., 2014) due to a wide array of technical, economic, social, and institutional factors. Lack of technological improvement and market imperfections have also often locked small producers into subsistence production and contributed to the stagnation of the sector (Shiferaw and Teklewold, 2007; Asfaw et al., 2010: 2011). These anomalies cause the need to better understand the adoption and use of improved legume technologies and the factors responsible for the low uptake.

In Ethiopia, accelerating agricultural growth remains one of the most urgent goals which mainly comprises strengthening legumes production and contributing to better food and nutrition security and more sustainable and profitable farming systems. Different improved varieties and legume technologies have been made available to smallholder farmers through the national agricultural extension system and various technology scaling projects (Kassa and Alemu, 2017). Studies on the adoption of agricultural technologies have attracted attention largely because agriculture is the main source of livelihoods for developing countries (Getachew, 2016). Consequently, a number of technology adoption studies were conducted to measure success towards reaching the national goals of reducing poverty, increasing food security and nutrition and improving foreign currency earnings (Abebe and Bekele, 2015; Yirga et al., 2015; 2016; Bishaw and Alemu, 2017; Alemu et al., 2018).

Although adoption of new technology and being ready for a change from the farmer's side is the policy interest in Ethiopia, the adoption rate of modern agricultural technologies and innovations for increasing production and income in the country is very low (Hailu et al., 2014; Zeng et al., 2017). According to Getachew (2016), a process of adopting agricultural technologies by farmers is still very slow despite various studies and extension efforts and calls for further studies. Information at national, regional, zonal and district level adoption and dissemination of improved grain legume technologies by smallholder farmers are scarcely available in the country (Yirga et al., 2015). The aim of this paper was to review the adoption, initiatives and strategic plans, opportunities, constraints, and emphases for future interventions for legume crops production and productivity in Ethiopia.

\section{Methodology}

This review adopted preferred reporting items for systematic literature review approach to search and select literatures relevant to the topic. A literature search for this review was restricted to articles published between 2000 and 2019 in different journals, research centers, annual and consultant reports available in different institutions affiliated with the national agricultural research system. The review focused primarily on literatures of studies conducted in Ethiopia and other developing African countries. Articles for this review were searched and identified from electronic databases such as Web of Science, AGRIS, Research Gate,
Science Direct, Taylor and Francis, Springer, different African and Ethiopian Journals, and libraries of the Ethiopian Institute of Agricultural Research (EIAR) and different National Research Institutes.

A total of about 150 articles were retrieved mainly focusing on empirical results reported on production and productivity of grain legumes, adoption of grain legumes in the production system, determinants and factors related to adoption of grain legumes production, initiatives, strategies and opportunities of legume crops production, and major constraints and challenges that needs due attention for improved adoption, production and productivity. Individual articles from the collected literatures were grouped with respect to the research objectives and content types. Research objectives and content types were further subclassified into articles focusing on the themes of the review. Following a critical review, sixty-four articles were used to develop the final review, most from studies conducted in Ethiopia and other African countries.

\section{Results and Discussions}

The review was organized according to the following literature themes: (1) the overview of grain legumes production and their importance in Ethiopia; (2) adoption level of legumes production and technologies by small scale farmers which sub-categorized into: (i) the need for adoption of grain legumes; (ii) adoption level of legume crops production in Ethiopia; (iii) determinants and factors influencing rate of legume crops adoption (3) initiatives and strategic plans for grain legumes production in Ethiopia, (4) opportunities that exist for legumes production and productivity in Ethiopia and (5) major constraints and challenges facing legumes and needs due attention for improved adoption, production and productivity; and (6) emphases and recommendations for future interventions concerning adoption and promotion of legumes, and enhancing their production and productivity for development of agricultural system in the country.

\section{Overview of Grain Legumes Production and Their Importance in Ethiopia}

Grain legumes belong to the family Fabaceae of the Angiospermae and are considered rich in high-quality proteins with significant impacts on the nutrition, diet, and health of many people across the world (Popoola et al., 2019). They are the edible seeds of plants of the legume family and they have in common that they grow in pods. They are harvested mature, can be dried and stored for longer periods without refrigeration, and marketed dry to be used as food or feed or processed into various products (Getachew, 2019).

Legume crops provide food for humans and feed for domestic animals (Popoola et al., 2019). They are a desirable commodity independent of whether they are viewed as a costeffective option for improving the diets of low-income consumers who cannot easily afford meat, dairy products and fish. In Ethiopia, legumes are the second most important element in the national diet and a principal protein source. Besides, legumes contain double or triple the amount of proteins as cereal grains do, provide calories and essential micronutrients and are low in fat and high in fiber, thus, reduce malnutrition and improves human health. They are can be 
consumed as boiled, roasted, or as a stew-like dish known as 'Wot' that accompanies the locally made bread called 'Injera' (Koroma et al., 2016).

Grain legumes are necessary elements of crop production in Ethiopia's smallholders' agriculture, providing various advantages to small farm holdings (Meselu, 2019). Ethiopian farmers produce different legume crops mainly for food and feed, to fetch cash, and more importantly to restore the fertility of the cropland. Among different legumes, faba bean (Vicia faba L.), field pea (Pisum sativum L.), chickpea (Cicer arietinum L.), lentil (Lens cultinaris Medik.), grass pea (Lathyrus sativus L.), fenugreek (Trigonella foenum-graecum L.) and lupine (Lupinus albus L.) are categorized as highland legume crops and grown in the cooler highlands. On the other hand, haricot bean (Phaseolus vulgaris L.), soya bean (Glycine max L.), cowpea (Vigna unguiculata L.), pigeon pea (Cajanuscajan L.) and mung beans (Vigna radiata) are categorized as lowland legume crops and predominantly grown in the warmer and low land parts of the country (Tegegne, 2017).

Grain legumes in Ethiopia cover about $13 \%$ of the total cultivated land that is 1.6 million hectares (ha) and provide $11.89 \%$ of the total crop production of the country, which is 2.67 million tons (CSA, 2015). The production by volume has been increased by $71.92 \%$ with a growth rate of $3.78 \%$ per annum for the duration of nearly 20 years and the area coverage by legume crops has been increased by $53 \%$ with a growth rate of $3 \%$ per year (Atnaf et al., 2015). Of the different legumes produced, faba beans account for nearly one-third of entire legume production, followed by haricot beans, field beans, and chickpeas (each around $14 \%$ of production) while other grain legumes, such as grass peas, lentils and white pea beans make up the remaining $25 \%$ (ITC, 2019). The participation of farmers in the production of legumes in the country has been increased nearly by twofold from 4.5 to 8.5 million farmers for the last 20 years (Atnaf et al., 2015). The trends of productivity in quintals per hectare of different legume crops in Ethiopia from 2007/2008 to 2017/2018 cropping year is indicated in Figure 1.

According to CSA (2018) report, grain legumes grown in $2017 / 18$ covered $12.61 \%(1,598,806.51$ hectares $)$ of the grain crop area and about $9.73 \%(29,785,880.89$ quintals $)$ of the grain production was obtained from the crops. Faba beans, haricot beans (white), haricot beans (red), and chickpeas were planted to $3.45 \%$ (about 437,106.04 hectares), $0.71 \%$ (about 89,382.68 hectares), $1.71 \%$ (about 216,803.91 hectares) and 1.91\% (about 242,703.73 hectares) of the grain crop area. The production obtained from faba beans, haricot beans (white), haricot beans (red), chickpeas and field peas were $3.01 \%$ (about 9,217,615.35 quintals), $0.48 \%$ (about 1,482,128.42 quintals), $1.22 \%(3,727,664.85$ quintals $), \quad 1.63 \% \quad(4,994,255.50$ quintals $)$ and $1.20 \%$ $(3,685,190.65)$ of the grain production, respectively. The mean annual global production of major grain legumes as adapted from Kebede (2020) is indicated in Table1.

While grain legumes are grown throughout the country, Oromia, Amhara, SNNPR and Tigray regions are the first four leading regions in producing grain legume crops in the country and take the largest percentage proportions which are $43.7 ; 39.47 ; 13.31$ and 1.19 , respectively. The total cultivated area under grain legumes in Amhara, Oromia, SNNPR, and Tigray regions is $0.68(42.40 \%) ; 0.62(39.91 \%) ; 0.24$ $(14.75 \%)$ and 0.037 (2.33\%) million hectares of land, respectively (Getachew, 2019). The author also revealed the average volume of production of top four grain legume producing regions in Ethiopia (in 000 quintals) during the last eleven years as shown in Figure 2.

There is increasing recognition of the importance of grain legumes in improving food and nutrition security, creating more sustainable and climate-resilient food systems (Koroma et al., 2016). When utilized in crop rotation and intercropping, legume crops can increase soil fertility, improve soil health and increase the yield of other crops. Because of their unique capacity to fix nitrogen from the atmosphere, they are able to make their own nitrogen fertilizer, play an important role in improving soil fertility and help in making farming systems more climate-smart (Vidigal et al., 2019). When the plant dies, it leaves nitrogen in the soil that crops other plants can take up, improve soil fertility and, thus, save fertilizer costs in subsequent (Koroma et al., 2016).

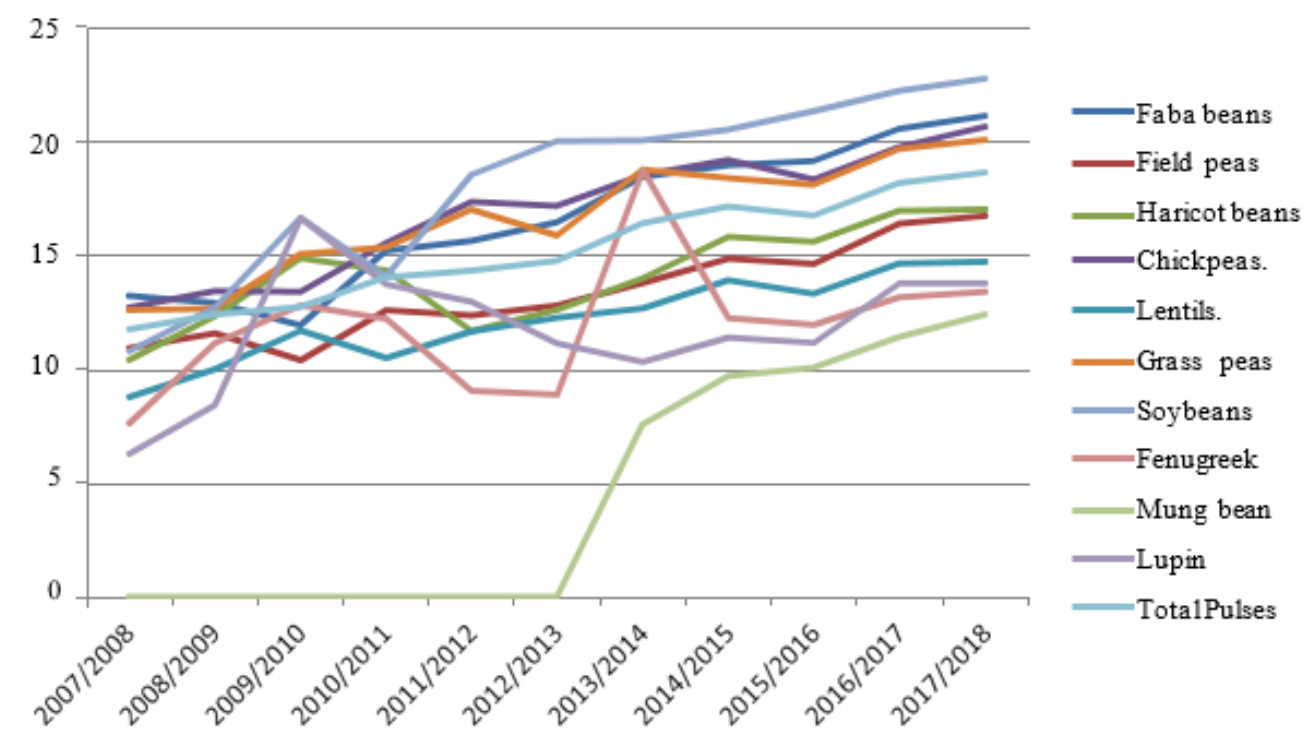

Figure 1. Trends of productivity (quintals per hectare) of different legume crops in Ethiopia from 2007/2008 to 2017/2018 cropping year. Source: Getachew (2019) using data obtained from CSA (Central Statistical Authority of Ethiopia) agricultural sample survey reports of 2008-2018. 


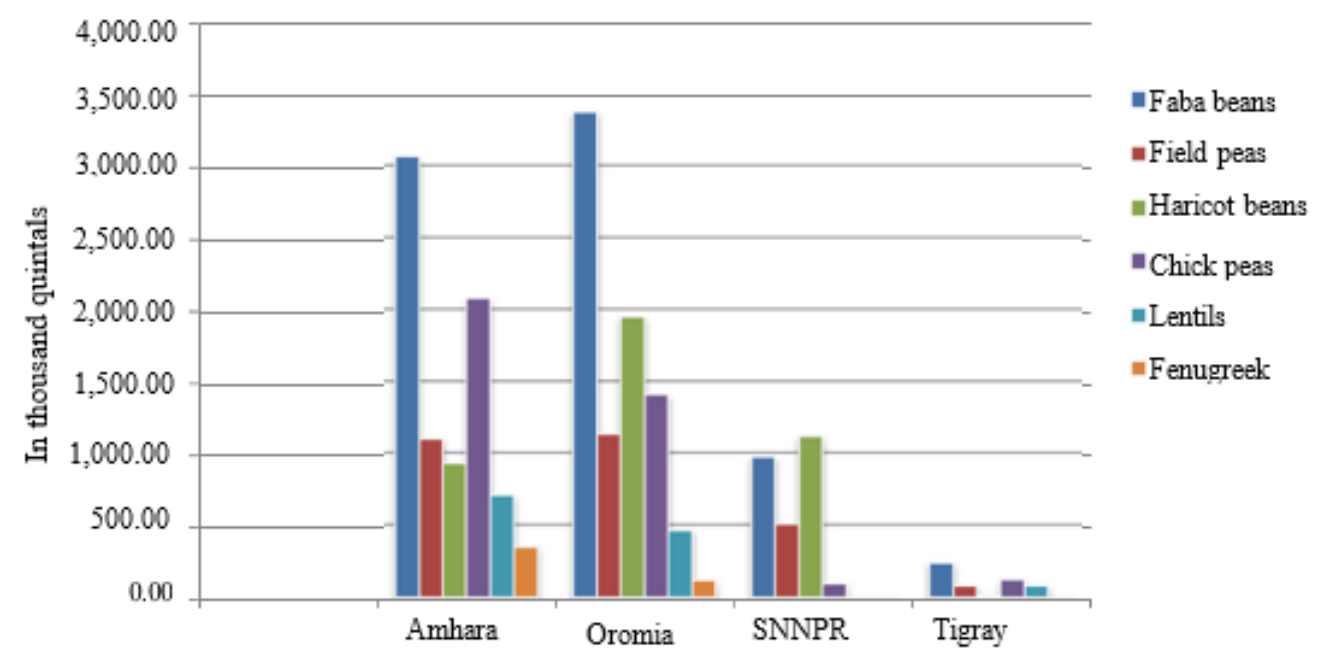

Figure 2. Average volume of production of top four grain legume producing regions (in 000 quintals) during the last eleven years. Source: Getachew (2019) using data adapted from CSA (Central Statistical Authority of Ethiopia) agricultural sample survey reports from 2008 to 2018.

Table 1. Mean annual global production of grain legume crops from 2008 to 2017

\begin{tabular}{l|c}
\hline \multicolumn{1}{c|}{ Grain legumes } & Production (tons) \\
\hline Haricot beans & $25,657,833.0$ \\
Field peas & $11,691,517.3$ \\
Chickpeas & $11,672,579$ \\
Cowpeas & $6,498,236.8$ \\
Faba beans (Broad beans) & $4,468,240.1$ \\
Lentils & $4,990,522.6$ \\
Pigeon peas & $4,449,435.9$ \\
Other grain legumes* & $6,254,656.9$ \\
Total grain legumes & $75,683,021.6$ \\
\hline
\end{tabular}

*Data for other grain legumes were determined by difference between total grain legumes production as reported by Food and Agriculture Organization (FAO) (2019) and the total of the seven grain legume crops listed in the above table. Source: Kebede (2020).

Legumes also improve the more intensive and productive use of land, particularly in areas where land is scarce and the crop can be grown as a second crop using residual moisture (Vidigal et al., 2019). Besides, legumes provide a source of cash incomes for smallholders because of their increasing importance and growing demand in local, regional and international markets (Asfaw et al., 2011; Ferede et al., 2014). Ethiopia ranks $6^{\text {th }}$ in chickpea production, and $14^{\text {th }}$ in the production of common bean. Among African countries, Ethiopia is the largest producer of both chickpea and common bean (Getachew, 2016). Grain legumes are the third-largest export crop of Ethiopia after coffee and sesame, contributing around USD 251 million to export earnings in 2013/14 (Meselu, 2019). The most important export legume crops include haricot beans, chickpeas (Kabuli type), faba beans, lentils and field peas (Getachew, 2019).

\section{Adoption of Legumes Production and Technologies} by Small Scale Farmers

The need for adoption of grain legumes

According to Melesse (2018), adoption is defined as the integration of innovation into farmers' normal farming activities over an extended period. Adoption can also be considered as a variable representing behavioral changes that farmers undergo in accepting new ideas and innovations in agriculture anticipating some positive impacts of those ideas and innovations. As stated by
Amanuel and Girma (2018), raising agricultural output and productivity on a sustainable basis necessitates large scale adoption and dissemination of new technologies such as legume-based technologies.

Adoption of new agricultural technologies and improved practices play a key role in increasing agricultural production, improving national food security in developing countries, stimulating overall economic growth through intersectoral linkages and conserving natural resources (Sanchez et al., 2009). Among agricultural technologies, the adoption of different grain legume technologies has a great advantage for a country like Ethiopia where the agriculture sector drives the entire economy and have a positive contribution towards food security, income improvement, household expenditure, poverty and generally on the welfare of farm households.

Ethiopian farmers' produce different legume crops mainly for food and feed, to fetch cash, and more importantly to restore the fertility of the cropland (Atnaf et al., 2015) and prevent land degradation while improving crop and livestock production on a more sustainable basis (Kassie, 2011). Most legumes produce several products and serve for various functions during their growth or after harvest and are often referred to as being multipurpose. These functions include generation of income, provision of food, fuel and livestock feed, soil fertility improvement through biological nitrogen fixation (BNF), soil erosion 
control, and a range of other benefits (Muoni et al., 2019). The adoption of such multipurpose crop, which enhances agricultural productivity while conserving the natural resource base, is helpful for achieving income and food security, and for reversing land degradation.

In a wider perspective, legumes have long been advocated for enhanced nutrition and preserving soil resources in low input agriculture although farmers' production of legumes is minimal in Ethiopia and even across most of sub-Saharan Africa (Kerr et al., 2007). Further, adopting pro-poor and environment-friendly legume technologies have the potential to increase agricultural productivity and help transform subsistence agriculture towards market-oriented and income-generating pathways (Asfaw et al., 2010). The adoption of legumes adapted to different agroecologies especially the semi- and arid tropics contribute to the diversity of cropping systems and diets of people living in these areas. According to Chibarabada et al. (2017), the adoption of grain legumes has been mainly linked to them being rich sources of protein, low in saturated fat, as well as possessing certain important micronutrients. Comprehensively, Kassie (2011) clearly indicated the potential for adoption of legume production and technologies to household welfare (income) and environmental conservation (Figure 3).

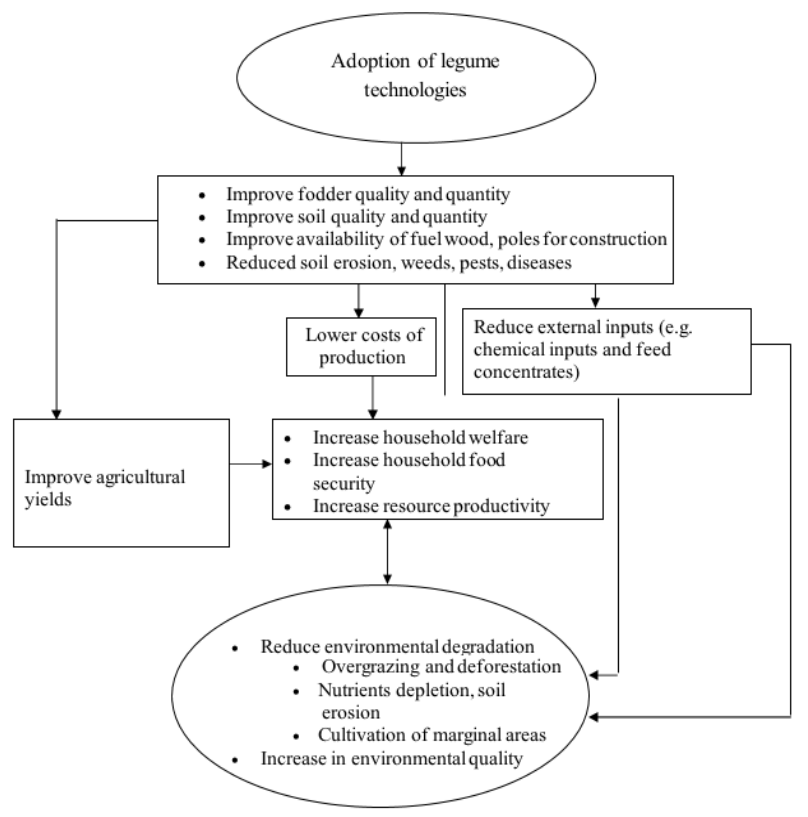

Figure 3. The potential for adoption of legume production and technologies to household welfare (income) and environmental conservation. Source: Kassie (2011)

The adoption and incorporation of legumes into the cereal-based farming system can provide services such as high quantity and quality fodder production, soil erosion prevention, and soil fertility restoration. Besides, legume adoption could increase yields of crops through breaking cycles of pests and diseases, improved soil structure, or increase of organic matter as a result of residual benefit. Residual benefits can also be accredited to an enhancement in the nitrogen economy of the soils (Kassie, 2011). For instance, results in Ethiopia showed that vetch, lablab, and clovers are capable of leaving 30-60 kg N/ha through their root systems when they are intercropped with cereal crops.

\section{Adoption Level of Grain Legumes Production in} Ethiopia

In Ethiopia, different grain legume technologies have been made available to smallholder farmers through the national agricultural extension system and various technology scaling projects (Alemu et al., 2018). These scaling up projects include legume research which is augmented by the CGIAR centers such as CIAT, ICARDA, ICRISAT and IITA supporting research for development projects of chickpea, lentil, faba bean, beans, grass pea in partnership with National Agricultural Research System (Bishaw et al., 2018). Besides, other projects such as Integrated Seed Sector Development (ISSD) (Bishaw et al., 2018), Tropical Legumes supported by the Bill \& Melinda Gates Foundation and Treasure Legumes project supported by IFAD (Asfaw et al., 2010) played a great role in enhancing the unexploited potential of legumes for the poor. A number of technology adoption studies were also conducted to confirm accountability for the legume investments made as well as to guide forthcoming research and development endeavors (Abebe and Bekele, 2015; Yirga et al., 2015; 2016; Bishaw and Alemu, 2017) and to measure success towards reaching the national goals of reducing rural poverty, increasing food security and nutrition and improving foreign currency earnings (Alemu et al., 2018).

Consequent to the present agricultural commercialization policy in Ethiopia, legumes have recently emerged as the third strategic agricultural export commodity next to coffee and sesame in making foreign exchange earnings for economic growth in Ethiopia (Ferede et al., 2014). Adoption and increasing the production and productivity of grain legumes is considered as an opportunity in reversing trends in low productivity, poverty and food insecurity in the country. The grain legume industries have also developed significantly with little intervention as there exists a great potential to increase the production and influence of legumes through practical and targeted support (Getachew, 2019).

In recent years, there has been increasing research interest across the different regions on the adoption and integration of legume crops into the agricultural systems with the objective of improving and sustaining soil fertility. Consequently, most of the legume crops are known to be ideal for enhancing soil fertility, as they are commonly fast-growing, nitrogen-fixing, efficient in taking and recycling nutrients, and easily decomposable (Amede, 2003). Much of the successes of adoption and production of legume sub-sectors have also been observed and accredited to the development and wide use of market preferred improved production technologies that have made substantial improvement in production and productivity (Ferede et al., 2014).

Grain legumes research program in Ethiopia has released a number of improved varieties to improve the productivity through developing and promoting enhanced cultivars with high and stable yield, and resistant/tolerant to significant biotic and abiotic stresses (Meselu, 2019). Despite the release of improved varieties, the use of certified improved seeds by farmers is low. MoA (2013) indicated that low agricultural technology adoption rates can have many reasons of which the important reasons are the substantial lack of improved seed and low use of available improved varieties. For instance, Meselu (2019) reported a low adoption rate of improved faba bean varieties based on the proportion of land allocated which is estimated to be $22.38 \%$ at a national level. 
Despite considerable initiatives and investments in improving the adoption, technology generation and positive contribution of legumes to the various systems, the adoption of legumes be it for food, feed or cover crops is very low (Amede, 2003). The capacity of the research system in enhancing the effectiveness of the agricultural extension services, creating a vibrant and dynamic national seed system and widespread use of grain legume technologies is limited (Odame et al., 2013). Further, Alemu et al. (2018) reported an over-all low level of adoption estimates with considerable variations among the crops and across regions of Ethiopia though there were higher adoption estimates in some regions and locations which suggest limited nature of promotion efforts of improved legume production and technologies. These authors also stated that the capacity and nature of formal seed system, limited investment in demand creation, ineffective seed demand assessment and supply are key determinants related to the adoption and use of diverse improved grain legumes.

Mtambanengwe and Mapfumo (2009) investigated the challenges associated with the adoption and usage of legumes and showed that the rate of adoption is low and has not significantly contributed to rural livelihoods although there had been successful testing of technologies. These authors indicated that land allocated to legumes was also small to make a significant impact reducing the adoption and contribution of legumes. According to Mtambanengwe and Mapfumo (2009), a strong focus of the farmers was maintained on the yields of nonlegume crops such as maize and sorghum especially in cropping systems where intercropping is practiced. On the other hand, Asfaw et al. (2010) showed that research centers and bureaus of Agriculture and Rural Development promoted some of the existing technologies; however, farmers' adoption of these technologies has been limited. Farmers also have different levels of adoption and the application may take a long time to be practiced by farmers for scaling up even though various crop agriculture technologies are considered as a principal.
Adoption estimates based on the household survey indicated that the adoption rates measured as the proportion of households and area share of improved varieties are also low (Yirga et al., 2016). Alemu et al. (2018) linked low adoption of grain legumes with the extent of use of released varieties as the adoption of improved legume varieties by smallholder farmers is low regardless of the release of a fairly good number of improved varieties. Asfaw et al. (2011) also showed that knowledge of existing varieties, perception about the attributes of improved varieties, household wealth (livestock and land) and availability of active labor force are major determinants for the adoption of improved production technologies. Chibarabada et al. (2017) indicated that breeding and crop improvement of grain legumes have been limited by the poor adoption of seed and the failure of breeders to improve farmers' varieties and tap into certain beneficial traits leads to low adoption and production. The estimates of adoption rate of improved major legume crops in different production areas of Ethiopia and the extent of varietal adoption of grain legumes are shown in Table 2 and Table 3, respectively.

\section{Determinants and Factors Influencing the Rate of Grain Legumes Adoption}

Several factors have been identified to determine the adoption, production and distribution of legumes and legume-based technologies, which could be contained under and well-defined by three relative factors as stated by Amede (2003); viz. i) socio-cultural, economic and political ii) agroecological and iii) management at farm level. According to Ferede et al. (2014), the adoption of agricultural technologies are influenced by a wide array of technical, economic, social, and institutional factors of which the two major factors are the main drivers of adoption of agricultural technologies in developing countries: (a) the availability and affordability of technologies; and (b) farmers' expectations that the use of those technologies remain profitable which in turn influenced by factors such as access to land, labor, prices, and profitability of agricultural enterprises.

Table 2. Estimates of adoption of improved major legume crops.

\begin{tabular}{|c|c|c|c|c|c|}
\hline Crop & EAR (\%) & Indicator & Area coverage & Year & Source \\
\hline Chickpea & $\begin{array}{c}19.4 \\
17.4 \\
25.6 \\
20.0 \\
7.0 \\
4.0 \\
12.5 \\
15.6 \\
2.6 \\
\end{array}$ & $\begin{array}{l}\% \text { of national chickpea area } \\
\% \text { of chickpea producers } \\
\% \text { of chickpea area } \\
\% \text { of chickpea area } \\
\% \text { of chickpea area } \\
\% \text { of chickpea area } \\
\% \text { of lentil producers } \\
\% \text { of lentil area } \\
\% \text { of lentil producers }\end{array}$ & $\begin{array}{l}\text { National } \\
\text { Oromiya } \\
\text { Benishangul Gumuz } \\
\text { Amhara } \\
\text { SNNP } \\
\text { National } \\
\text { Amhara }\end{array}$ & 2013 & $\mathrm{~S} 1$ \\
\hline Lentil & $\begin{array}{c}2.2 \\
30.1 \\
38.6 \\
19.6\end{array}$ & $\begin{array}{l}\% \text { of lentil area } \\
\% \text { of lentil producers } \\
\% \text { of lentil area } \\
\text { Full adopters }\end{array}$ & $\begin{array}{l}\text { Amhara } \\
\text { Oromia } \\
\text { Oromia }\end{array}$ & 2013 & S2 \\
\hline $\begin{array}{l}\text { Faba bean } \\
\text { Common beans }\end{array}$ & $\begin{array}{c}1.9 \\
22.38 \\
79\end{array}$ & $\begin{array}{l}\text { Partial adopters } \\
\% \text { of faba bean area } \\
\% \text { of common bean producers }\end{array}$ & $\begin{array}{l}\text { National } \\
\text { Central Rift Valley }\end{array}$ & $\begin{array}{l}2014 \\
2015\end{array}$ & $\begin{array}{l}\mathrm{S} 3 \\
\mathrm{~S} 4\end{array}$ \\
\hline
\end{tabular}

EAR: Estimated adoption rate (\%); S1: Yirga et al. (2015; S2: Yirga et al. (2016); S3: Bishaw and Alemu (2017); S4: Abebe and Bekele (2015); Source: Alemu et al. (2018). 
Table 3. The extent of varietal adoption in grain legumes in Ethiopia

\begin{tabular}{l|llrr}
\hline \multicolumn{1}{c}{ Crop } & \multicolumn{1}{c}{ No of varieties reported by farmers } & Major varieties & FA (\%) & YR \\
\hline \multirow{2}{*}{ Chickpea } & \multirow{2}{*}{ Nine varieties of 23 released varieties } & Arerti & 9.61 & 2000 \\
& & Shasho & 5.23 & 2000 \\
\hline Lentil & Two varieties of 11 released varieties & Alemaya & 11.42 & 1998 \\
\hline \multirow{2}{*}{ Faba bean } & \multirow{2}{*}{ Six varieties of 31 released varieties } & CS-20-DK & 2.54 & 1977 \\
& & Degaga & 2.23 & 2002 \\
\hline \multirow{2}{*}{ Field pea } & Three varieties of 35 released varieties (\% of & Adi & 1.10 & 1995 \\
& total area) & Mohanderfer & 0.37 & 1979 \\
& & Tegegnech & 0.06 & 1994 \\
\multirow{2}{*}{ Haricot bean* } & & Awash 1 & 39.5 & 1990 \\
& \multirow{2}{*}{ Five varieties from 57 varieties released } & Awash melka & 5.6 & 1998 \\
& & Nasir & 47.4 & 2003 \\
\hline
\end{tabular}

FA: \% of farmers adopting; YR: Year of release; Note: *Represents estimates from rift valley areas of the country (Melkassa Agricultural Research Center, 2016). Sources: Alemu et al. (2018).

Studies have also indicated that labor requirements, seed access and appropriate genotypes (varieties) are determinants of legumes production and technology adoption and intensification (Kamanga et al., 2001; Kerr et al., 2007). Kerr et al. (2007) further stated that different biological properties of legumes present challenges to rate of adoption of legumes which includes: i) the moderate yield of legumes compared to cereals and tubers; ii) the high labor requirement associated with a crop of initially slow growth habit; and iii) relatively few large seeds are produced per plant, necessitating the use of large amounts of seed (on a weight basis) per land area, which substantially increases establishment costs compared to cereals.

Different socio-economic aspects also act as determinants to farmers for adopting and producing legumes. These include: i) limited and uncertain market access; ii) unstable and highly variable prices for legume products across locations and time; iii) limited farmer access to seeds of improved legume genotypes; and iv) insufficient attention by researchers to the multifunctionality of legumes (Kerr et al., 2007). A report by Amede (2003) also indicated that three factors determine the decision of farmers to grow or not to grow legumes and adopt legume technologies. These are: i) In subsistence farming, the food habit dictates the amount of land to be allocated for various crops and the type and amount of input invested per crop. ii) The fertility status of the land and the incidence of pests and diseases dictate the frequency of legumes in the cropping systems i.e. the proportion of legumes usually increases with the decline in soil productivity and increased incidence of pests and diseases. iii) The market value of respected crops may dictate how much land is allocated for legumes.

Evidences have also showed that problems related to market reduced the adoption and production of legumes (Ferede et al., 2014). In addition, the legume export is not competitive in terms of price, quality and volume so that the local market accounts for the largest share $(80 \%)$ of the legumes trade volume (Shiferaw et al, 2007). As a result, the involvement of smallholder farmers into legumes production and their integration into the market economy remains limited. At large, adoption of agricultural technology is influenced by a set of independent variables like farmer and household characteristics (such as age, gender, education level, and family size), psychological factors (such as attitudes to and perceptions of improved inputs), socioeconomic factors (such as farm size, land size, number of livestock and income), institutional factors (such as credit, extension, membership in cooperatives and infrastructure like access to roads) (Ayele and Bosire, 2011).

\section{Initiatives and Strategic Plans for Grain Legumes Production in Ethiopia}

Cognizant to the importance of the agricultural sector, different agricultural production enhancing initiatives, strategies and measures have been adopted in Ethiopia. The main purpose of such initiations and strategies are to increase the production and productivity of farmers thereby increasing their level of commercialization that eventually improves the nutritional status of households and reduces poverty (Tafese, 2018). Historically, in Ethiopia, efforts to generate and adopt improved food legume technologies adapted to local conditions and demonstration trials on farmers' fields to encourage uptake of different technologies dates back to the early 1970s. Consequently, the Ethiopian government has launched a number of initiatives and strategies aimed at increasing the competitiveness of smallholder farmers in the legumes sector realizing the immense potential of grain legumes to supply high-quality products for both the domestic and export market, increase farm income and contribute to food security (Yirga et al., 2015).

According to Getachew (2019), the government of Ethiopia is taking various policy measures that used to develop the potential of the legume subsector and to increase the competitiveness of smallholder farmers. These policy initiatives paved the initial path for private sector participation in the legumes sector, which contributes to improvements in adoption, production and marketing. The prominent initiatives include the generation, adaptation and promotion of improved food legume production technologies involving high yielding varieties, adoption and use of recommended fertilizer rates and crop protection practices, market liberalization, promotion of grain legumes export trade and financing incentives aimed at enhancing the competitiveness of exporters (Yirga, 2010; Yirga et al., 2015).

The Ethiopian Institute of Agricultural Research, through its outreach program, the agricultural extension agents, and the agriculture bureaus of the regional states, were also involved in demonstrations and scaling up of proven grain legume technologies to farmers (Yirga et al., 
2015). The Ethiopian Pulses, Oilseeds and Spices Exporters Association (EPOSPEA) is an association for private sector actors involved in the production, processing, marketing and trade of legume products (Koroma et al., 2016). Besides, the Ethiopian rural development policy and strategy document have also given weight to follow diversification and specializations in production systems along with improved access and use of agricultural technologies as one of the approaches to ensure households' food security (Amanuel and Girma, 2018).

The Agricultural Transformation Agency (ATA) has been established to address specific systemic bottlenecks by strengthening capacities, introducing new technologies and approaches to accelerate agricultural development in Ethiopia. One of these approaches is the agricultural commercialization cluster approach, which involves using a market-driven and geographically based approach to accelerate the transition of farmers from subsistence to commercial orientation. Accordingly, ATA has started working in the four major legume producing regions of Ethiopia (Oromia, Amhara, SSNP and Tigray region). Through the cluster approach, a number of grain legumes have been prioritized, particularly, chickpeas and haricot beans in Oromia and Amhara region, but also lentils, faba bean and soybeans (Koroma et al., 2016).

The Agricultural Transformation Agency has also recently started organizing and legalizing the formation of seed producer cooperatives which are emerged as a major force of farmer-based seed production and recognized as an intermediate sector. These seed producer cooperatives in Ethiopia played an important role in seed delivery filling the seed demand gap of the formal sector. Bishaw et al. (2018) indicated that about 273 seed producer cooperatives were organized and supported to engage in seed business in potential Agricultural Growth Program (AGP) districts, moisture stress areas in Productive Safety Net Project (PSNP) districts and non-AGP and non-PSNP districts during 2009 to 2015 of which 98 seed producer cooperatives have been engaged in grain legume seed production (Table 4). Some of these cooperatives evolved from farmer research groups established for adaptive research, participatory variety selection, pre-extension technology demonstration or pre-scaling up/out activities by National Agricultural Research System while others were established by public seed enterprises for contractual seed production or by NGOs and projects for local seed production.

International Crops Research Institute for the SemiArid Tropics (ICRISAT) in collaboration with the Ethiopian Institute of Agricultural Research (EIAR) has also developed several high-yielding and stress-tolerant varieties of legumes, especially chickpea, with desirable agronomic and market traits to harness the untapped potential of legumes for the poor. As a result, a total of eleven improved chickpea varieties had been released as a result of this research program (Asfaw et al., 2011). Besides, ICRISAT initiated two major legume projects: (Tropical Legumes II) supported by the Bill \& Melinda Gates Foundation and Treasure Legumes project supported by IFAD to address the constraints in production and enhance the unexploited potential of legumes for the poor (Asfaw et al., 2010).
The technology promotion and decentralized seed production efforts by Farmer Research Group (FRG) and Tropical Legumes (TL) projects are outlined to provide a glimpse of the design followed (Habte et al., 2018). The approach involves demand creation by promoting and providing information followed by multiplying of seeds of legume varieties demanded by farmers. For instance, the decentralized seed production and dissemination initiative of the common bean technology scaling up effort has been employed and gave rise to increased demand for improved varieties and associated practices (Teshale et al., 2006).

\section{Opportunities That Exist for Grain Legumes Production in Ethiopia}

Ethiopia has varied agro-ecology, especially great variation in altitude ranging from sea level up to 4500 meters, which permits different agricultural systems and production of different crops (Getachew, 2019). Besides, the variation in climatic conditions and soil types makes Ethiopia more suitable for growing of a variety of crops including legume crops. On the other hand, there is a large diversity of grain legumes that fit into various agroecologies in the country. Thus, there is an opportunity that different grain legumes are to be adopted and promoted to increase production and productivity, dietary diversity and there is a prospect to broaden and increase the grain legumes research, development and innovation.

Ethiopia is the second most populated country in Africa (after Nigeria) and the population of Ethiopia is projected to reach 130 million people in 2030 (Bekele and Lakew, 2014). This population is expected to double by the year 2050 compared with 2010, and the per capita domestic grain legume demand is expected to increase by $62 \%$ in Ethiopia (van Loon et al, 2018). Population growth combined with rising incomes is expected to be the main driver for sustained demand for legume crops offering huge potential for domestic and regional investment in legume crops production. In addition, Ethiopians have a fasting period of over 200 days a year, and a range of grain legumes is consumed during this fasting period (Koroma et al., 2016). Therefore, the option that looks more likely is increasing yield through intensification and adoption of different legumes together with the adoption of different improved agricultural practices and technologies.

The ambition to increase value addition in the agricultural value chain through processing is essential in Ethiopian agricultural growth strategies (Koroma et al., 2016). Ethiopia has also a number of grain legumes processing factories. According to Getachew (2019), grain legumes industry has developed significantly throughout the country with little intervention, and great potential exists to increase the production and impact of legumes through proactive and targeted support. These offer an opportunity to stabilize and increase supply by improving production and quality up to the full potential which can meet domestic demands and ensure food security.

Grain legumes, especially haricot beans (red kidney beans), are produced through major cooperatives that exist along the major regions of Ethiopia (ITC, 2019). Cooperatives in Ethiopia are also moving towards agroprocessing of grain legumes such as chickpea, taking advantage of tax exemptions granted to cooperatives (Koroma et al., 2016). Therefore, the initiation of these 
cooperatives and improved income realized from agroprocessing could promote an opportunity for legume crops production. The opportunities that exist in agro-processing could also lead to the opening of new markets through value addition and product diversification. On the other hand, the demography and urbanization development of Ethiopia is also attractive to different agricultural investments (Getachew, 2019). Moreover, rapid urbanization is driving the growing demand for processed food based on grain legumes. This offers opportunities for employment and entrepreneurship in both large and smallscale industries and could be an attractive sector for rural and urban youth and small-scale farmers around urban to be involved in legumes production.
Ethiopia has prioritized the development of livestock sectors in order to increase the domestic production of meat and dairy products (Koroma et al., 2016). Besides, the demand for legumes and their residues as animal feed is growing due to changing diets. Stalks of different legume crops such as faba beans and lentils are used as animal feed and provide additional income to farmers involved in the production of legumes (van den Broek 2014). There is a growing demand for soybean meal for the poultry industry in Ethiopia as soybean meal is used in the production of animal feed for pets and livestock. Such development of livestock sectors and the high demand for animal feed leads to increased production of animal feed in the region which could provide a strong foundation for producing and developing regional value chains in grain legumes.

Table 4. Number of seed producer cooperatives established and engaged in legume seed production in 2015

\begin{tabular}{l|cccccccc}
\hline \multirow{2}{*}{ Region } & \multicolumn{3}{|c}{ AGP } & \multicolumn{2}{c}{ PSNP } & \multicolumn{2}{c}{ Non AGP/PSNP } & \multicolumn{2}{c}{ Total } \\
\cline { 2 - 9 } & Total & Legumes & Total & Legumes & Total & Legumes & Total & Legumes \\
\hline Amhara & 16 & 8 & 16 & 6 & 40 & 4 & 72 & 18 \\
Oromia & 30 & 22 & 43 & 28 & 46 & 12 & 119 & 62 \\
SNNPR & 7 & 0 & 19 & 2 & 8 & 7 & 34 & 9 \\
Tigray & 4 & 1 & 7 & 8 & 37 & 0 & 48 & 9 \\
Total & 57 & 31 & 85 & 44 & 131 & 23 & 273 & 98 \\
\hline
\end{tabular}

AGP: Agricultural Growth Program; PSNP: Productive Safety Net Project; SNNPR: Southern Nations, Nationalities, and People's Region. Sources: Bishaw et al. (2018).

The presence of relatively well-established export markets and the availability of a range of improved varieties of legumes (developed through strong national research program) are also the opportunities that can be harnessed to boost both the production and marketing of this commodity. Habte et al. (2018) reported that the opportunities for grain legumes particularly common bean is the presence of a favorable policy environment which encourages market-oriented production and incentive for farmer-based organizations to participate in the international market. Particularly, increasing international demand for common beans and mung beans is an excellent opportunity for farmers to increase production, export market and research and development actors to develop and promote technologies that meet such demands.

In addition, the country is moving towards improvement in different infrastructures, especially roads, linking major production areas with market places and progresses in accessing price information (because of expansion in coverage of mobile phones) (Habte et al., 2018). These are expected to reduce the transaction cost of marketing legumes thereby providing incentives for increasing the quantity and quality of production. The opportunities for market development and commercialization are particularly favorable for legume crops which tend to have higher domestic, regional and international demand.

More recently in Ethiopia, legumes became a substitute for meat due to exceptionally high prices of beef and mutton; households could have shifted to the consumption of legumes. The fact that legumes are often consumed by the low-income groups because they cannot afford meat products (FAO, 2015) and the unusually high meat price increase offers an opportunity of growing legume crops and becoming more attractive and profitable (Getachew, 2019).

Grain legumes mature early than other crops and this may help farmers to resist water shortage. This also helps to keep household food secured till the other crops are harvested and the fund from the sale of early harvested legume crops used to buy labor to harvest other crops and to cover other immediate expenses (Getachew, 2019). On the other hand, legumes have a natural ability to maintain soil through nitrogen-fixing, which improves yields of other crops, and result in savings for smallholder farmers from less fertilizer use (Yirga et al., 2010; FAO, 2016). This property is very essential and could be an opportunity for farmers especially where the soil degradation and nutrient depletion is the main causes of low agricultural productivity and high food insecurity (Gashaw et al., 2014; Birhanu, 2014; Adugna et al., 2015).

\section{Constraints and Challenges Facing Grain Legumes \\ Production}

A number of constraints and considerable challenges prevail in legumes production and productivity along with their value-chain (Atnaf et al., 2015). Although legumes have many desirable characteristics in terms of nutrition and environmental benefits, in most parts of Ethiopia they are considered as secondary crops which makes them not to be included in the investment resources and policy attentions (Getachew, 2019). Compared to cereal crops (teff, wheat, maize, barley, sorghum and millet), legume crops receive less quantity of land resources and other inputs (Demelash, 2018). The use of irrigation, improved seeds, fertilizers and chemicals to control pests and diseases allocated for legume crops are also not satisfactory and limited causing low productivity of legume crops (Getachew, 2019). 
Major production constraints for legumes are the absence of links to seed suppliers and value chains, lack of improved seeds and a high use of local varieties (on more than 95\% of the total cropped area) (Yirga, 2010), inadequate farm management practices, underdeveloped infrastructures, and population pressure and land fragmentation (Ronner and Giller, 2012). Low soil fertility in the high potential areas is another problem, while fertilizer use on legume crops is usually low (Asfaw and Shiferaw, 2009). According to Agegnehu (2018), poor soil fertility, soil acidity and the associated low phosphorus availability are among the major constraints affecting the production and productivity of food legumes in Ethiopia.

Tsegaye et al. (2015) and Getachew (2019) indicated that the productivity of legume in Ethiopia is severely constrained by four major factors, which are limited or no use of chemical fertilizers, improved seeds, limited use of conventional agronomic practices, and human factors such as access and control over resources. Water-logging, drought, poor management and lack of improved technology also limit legumes productivity. Schneider and Anderson (2010) also explained that diseases such as mildew, rust and the wilt/root-rot complex are the most important biotic constraints facing legume crops production in Ethiopia. According to Yirga (2010), production and productivity of legume crops are below potential due to low input usage, limited availability of seed and limited familiarity with the variety of existing legume types, and; limited usage of modern agronomic practices.

Research and extension services in Ethiopia are very often weak and information provided is usually focused on technical issues, and not able to take into account the complexity of agricultural intensification systems. Specifically, weakly developed input supply systems for seed, inoculants, fertilizers, herbicides and pesticides and machinery services can be existing challenges to improve the production of grain legumes (Koroma et al., 2016).

Marketing is another reason for the low production as a poor linkage between producers and the market has been observed to hinder producers' willingness to produce more legumes. Lack of technological change and market imperfections have often locked small producers into subsistence production and contributed to the stagnation of the legumes sector (Shiferaw and Teklewold, 2007; Asfaw et al., 2011). Weak linkage between the producers and the export markets, the fragmentation of intermediaries between the producer and consumer markets, inadequate market intelligence, inability to leverage scale efficiencies due to smaller size, non-conducive business environment due to missing credit and insurance and inconsistent policy interventions limited the production of legumes by small scale farmers (Atnaf et al., 2015).

As reported by Yirga (2010), much of the grain legumes produced in Ethiopia, which is approximately 65 to 90 percent, is consumed on-farm and only the remainder is marketed indicating that smallholder farmers primarily produce legumes for subsistence needs, and thus, the income benefit is not well realized. Consequently, grain legumes have become a poor and slow income-generating source for smallholder farmers, acting as a disincentive to their continued production despite the benefits associated with them. The very limited numbers of private seed enterprises and the low attention given to the informal seed sector has also narrowed the options available to farmers for obtaining modern varieties at affordable prices, at the right place and time (Asfaw et al., 2011).

The absence of effective linkage between indigenous knowledge and conventional ones has also been identified as one of the major constraints that hinder the effective development of agriculture in general and agricultural research and extension systems in particular. However, integration of appropriate indigenous knowledge systems into development programs has contributed to efficiency; effectiveness and sustainable development impact (Degaga and Angasu, 2017). Farmers' knowledge of the nitrogen fixation characteristic of legumes, associated with soil fertility improvement, and other functions including the provision of livestock feed and fuel are not well articulated, making it difficult for them to see the diverse plants.

In wider, Muoni et al. (2019) indicated that legumes production and productivity are lower than expected in east Africa including Ethiopia due to several reasons despite the various benefits offered by them. The author identified five important constraints viz.: (1) farmer unwillingness to test legumes species that are new to them due to limited resources and technologies; (2) insecure land tenure system in smallholder farms; (3) limited access to inputs and output markets; (4) high disease and pest incidences associated with management of legumes and (5) cereal dominated farming system.

\section{Emphases and Recommendations for the Future Interventions}

The production and productivity gap of legume crops can be minimized through the adoption and utilization of improved production technology to enhance smallholder farmer's income and their food security. There should be more integration of indigenous and scientific knowledge to allow farmers to improve grain yield and quality. Innovative approaches such as nutrition and education outreach are also required for farmers involved in legumes production. Besides, information on a better understanding of gender relations, household variation, consumption preferences and household resources are crucial in determining whether legume introduction leads to positive nutritional outcomes.

Essential interventions and enabling actions can strengthen the legumes production and productivity, and value chain to be productive and stable, and provide yearround transactions that supply domestic and international markets. According to Yirga (2010), access to inputs is a key step in bridging the yield gap between current and potential production. Thus, production technologies should be supplied to farmers, along with knowledge on how to adopt and use them effectively, seed multiplication should be increased to adequately supply the needs of farmers, exporters and domestic demand. It is also important to be more focused on the provision of regional-specific input packages, development of new varieties appropriate for export and leverage of cooperatives to provide reliable input supply and off-take. Moreover, legume breeding should be expanded especially in producing potential varieties to be used in the country. 
With increased packages and promotion of grain legumes, there is an opportunity to exploit the genetic resources of different legume crops. In addition, various researches also need to be done to assess the nutritional profile and product development of grain legumes as this would be more important and informative to dietary intake and lead to improved utilization of grain legumes. Thus, extension packages and improved legume technologies should also be incorporated into the agricultural curriculum of the country. Especially, knowledge and perception about the improved legume varieties are the supporting factors for adoption despite limited access.

Farmers require information on improved technologies and market access to purchase inputs and sell products to realize the benefits that are associated with their products. Therefore, the use of available indigenous technical knowledge especially the legume-based farming systems will enhance production and productivity, improve the agricultural sector and increase the sector contribution. A value chain approach should also be targeted in improving access of smallholder farmers to input and output markets. An in-depth value chain analysis is necessary to understand the market and provide support in improving both the input and output (grain) markets.

Therefore, farmers should be given awareness on the adoption of improved production technologies and inducing broad-based market participation that transmits excess supply of legumes to distant locations. Stronger linkages between smallholders and exporters are of paramount importance in leading a more efficient value chain especially to ensure where demand signals are clearly communicated to the producers, and where inputs are available to ensure proper production of the crop. Thus, actions that enable consistent supply between producers and exporters should be facilitated.

The development of infrastructures and facilities (road, transport, telecommunication, etc.) are also necessary to reduce marketing/transaction costs which often affect competitiveness in the world market. A policy for the provision of better credit services and increased supply of seed to local markets may help farmers to enhance the level of adoption of legumes production. This implies that the need for policy to strengthen and power government extension services and rural institutions to promote and create positive awareness about the existing improved technologies. Therefore, the government will need to take the lead in technology promotion and dissemination at the initial stages and in creating an enabling environment for effective participation of the private sector.

Beside their emergence as superior force and their considerable efforts, cooperatives dealing with agricultural productions especially seed producer cooperatives were not homogeneous entities and as diverse as their origin and vary in terms of structure, membership, governance, legality, crops, capital, capacity, facilities, geographic coverage and more (Bishaw et al., 2018). Therefore, further strengthening of these cooperatives and other farmer-based seed production programs and revolving seed schemes by improving farmers' skills in seed multiplication can assist in increasing the supply of seed for improved legume varieties both within communities and the formal seed system. In addition, a more flexible seed system which is financially and institutionally sustainable, that meets the needs of a diverse group of farmers, and reduces the current seed supply shortage is crucial to accelerate agricultural growth and commercialization further This also allows farmers sourced from different seed systems, according to their needs and investment possibilities.

Adequate resources should be devoted to the development and promotion of improved technologies, technology development efforts should target traits of legumes demanded by the producers and the markets. For instance, mungbean and cowpea are getting increasing importance in the world market (mungbean) and food and feed crop (cowpea) particularly in drought-prone areas of agro-pastoral farming systems of Ethiopia (Habte et al., 2018).

Although national-level multi-stakeholder platforms to promote the development of specific agricultural value chains exist in Ethiopia (Koroma et al., 2016), a different regional platform for grain legumes should be further established to address specific bottlenecks affecting the production and trade of grain legumes. A well-designed promotion strategy and effective extension service and platforms are also important in bringing different actors along the value chain and their interests together, and thus, need to be further strengthened.

According to the International Trade Centre (2019), advances in production techniques through targeted investment and knowledge transfer could increase total legumes production and raise smallholder income by between $40 \%$ and $70 \%$ per hectare. Thus, the Government of Ethiopia has to further recognize the potential of legume sectors and promote modern agronomic practices that increase legume production and productivity.

\section{Conclusions}

In Ethiopia, grain legumes have recently emerged as a strategic agricultural commodity in improving food security, creating more sustainable and climate-resilient production systems. The adoption and increasing the production of grain legumes is considered as an opportunity in reversing trends in low productivity, poverty and food insecurity in the country. The government of Ethiopia is currently taking various policy measures and strategies to develop the potential of legumes subsector and to increase their production and productivity. In spite of all this, this review paper revealed that the level adoption and production of grain legumes, be it for food, feed or cover crops, is still remained low and limited. A number of production constraints of grain legumes have been identified including weak policy attentions, limited use of production inputs, inadequate management practices, weak research and extension services, weak infrastructures, market problems and others. Prospects and opportunities for enhancing production and productivity are offered by varied agro-ecology, diversity of grain legumes, population and urbanization trends, increased demand for animal feed and processed foods. Furthermore, increasing production techniques, packages and promotion of grain legumes, improving technologies and market 
access, creating awareness and integration of indigenous knowledge, and development of facilities needs due attention and more emphases to improve grain legumes adoption, production and productivity.

\section{References}

Abebe Y, Bekele A. 2015. Analysis of adoption spell of improved common bean varieties in the central rift valley of Ethiopia: A duration model approach. Journal of Agricultural Economics and Development, 4(3): 037-043.

Adugna A, Abegaz A, Cerdà A. 2015. Soil erosion assessment and control in Northeast Wollega, Ethiopia. Solid Earth Discuss, 7(4): 3511-3540. doi:10.5194/sed-7-3511-2015

Agazhi ZD. 2016. Adoption and welfare impact of improved food legume technologies in bale highlands of Ethiopia: intra and inter-household empirical analysis. MSc Thesis, Haramaya University, Haramaya, Ethiopia.

Agegnehu G. 2018. Soil Fertility and Crop Management Research on Cool-season Food Legumes in the Central Highlands of Ethiopia. Ethiop. J. Agric. Sci., 28(1): 95-109.

Alemu D, Yirga C, Bekele A. 2018. Adoption of Improved Grain Legume Technologies in Ethiopia: Implications for Research, Extension and Seed System. Ethiop. J. Crop Sci., Special Issue 6: 3 .

Amanuel A, Girma A. 2018. Production Status, Adoption of Improved Common Bean (Phaseolus vulgaris L.) Varieties and Associated Agronomic Practices in Ethiopia. J Plant Sci Res., 5: 1: 178.

Amede T. 2003. Pathways for fitting legumes into East African highland farming system: A dual approach. In Grain Legumes and Green Manures for Soil Fertility in Southern Africa: Taking Stock of Progress. Proceedings of a Conference (8-11 October 2002), Leopard Rock Hotel, Vumba, Zimbabwe, 21-32.

Asfaw S, Shiferaw B, Simtowe F, Hagos M. 2011. Agricultural technology adoption, seed access constraints and commercialization in Ethiopia. Journal of Development and Agricultural Economics, 3(9): 436-447. https://ssrn.com labstract $=2056976$

Asfaw S, Shiferaw B, Simtowe F, Muricho G, Abate T, Ferede S. 2010. Socioeconomic Assessment of Legume Production, Farmer Technology Choice, Market Linkages, Institutions and Poverty in Rural Ethiopia. Research Report no. 3. Patancheru 502 324, Andhra Pradesh, India: International Crops Research Institute for the Semi-Arid Tropics. 84 pp.

Asfaw S, Shiferaw B. 2009. Baseline Assessment of Groundnut, Chickpea and Pigeon pea for Eastern and Southern Africa: Baseline research report for Tropical Legumes-II. Lilongwe: ICRISAT.

Atnaf M, Tesfaye K, Dagne K. 2015. The Importance of Legumes in the Ethiopian Farming System and Overall Economy: An Overview. American Journal of Experimental Agriculture, 7(6): 347-358. DOI: 10.9734/AJEA/2015/11253

Ayele S, Bosire C. 2011. Farmers' use of improved agricultural inputs and practices: Review and synthesis of research in Ethiopia. Nairobi, Kenya: ILRI. https://hdl.handle.net $\underline{/ 10568 / 5437}$

Bekele A, Lakew Y. 2014. Projecting Ethiopian Demographics from 2012-2050 Using the Spectrum Suite of Models. Ethiopian Public Health Association (EPHA), Addis Ababa, Ethiopia.

Birhanu A. 2014. Environmental degradation and management in Ethiopian highlands: Review of lessons learned. Journal of Environmental Protection and Policy, 2(1): 24-34. doi: 10.11648/j.ijepp.20140201.14

Bishaw Z, Alemu D. 2017. Yield gaps, varietal adoption, and seed commercial behaviour: Faba Bean Seed System in the Highlands of Ethiopia. Highlands of Ethiopia Policy brief. ICARDA.
Bishaw Z, Tiruneh AM, Atilaw A, Ayana A. 2018. Strategies and Innovative Approaches for Food Legumes Seed Delivery in Ethiopia. Ethiopian Journal of Crop Science, Special Issue 6(3), pp. 467-501.

Chibarabada TP, Modi AT, Mabhaudhi T. 2017. Expounding the Value of Grain Legumes in the Semi- and Arid Tropics Sustainability, 9: 60. doi:10.3390/su9010060

CSA (Central Statistical Authority). 2015. Agricultural sample survey: Report on area and production of major crops (Private peasant holdings, Meher Season). Volume Statistical Bulletins 584, Addis Ababa, Ethiopia.

CSA (Central Statistical Agency) of Ethiopia. 2018. Agricultural Sample Survey, Area and Production of Major Crops (Private Peasant Holdings, Meher Season).

Degaga J, Angasu B. 2017. Assessment of Indigenous Knowledge of Smallholder Farmers on Intercropping Practices in West Hararghe Zone; Oromia National Regional State, Ethiopia. Journal of Agricultural Economics and Rural Development, 3(3): 270-278.

Degye G, Belay K, Mengistu K. 2013. Is food security enhanced by agricultural technologies in rural Ethiopia? African Journal of Agricultural and Resource Economics, 8(1): 58 - 68.

Demelash BB. 2018. Common Bean Improvement Status (Phaseolus vulgaris L.) in Ethiopia. Adv. Crop. Sci. Tech., 6: 347. Doi: $10.4172 / 2329-8863.1000347$

FAO (Food and Agricultural Organization). 2015. Analysis of price incentives for haricot beans in Ethiopia. Technical notes series, MAFAP, by Workao TK, MasAparisi A, Lanos B, Rome, Italy.

FAO (Food and Agricultural Organization). 2016. Pulses are praised for their health, environmental and economic benefits. How can their full potential be tapped? http://www.fao.org/fsnforum/activities/discussions/pulses

Ferede S, Yigezu YA, Kemal S, Aw-Hassan A. 2014. Trends in Global and National Grain Legume Production and Trade: Implications on Local Chickpea and Lentil production Dynamics: The Case of Gimbichu and Minjar-Shenkora Districts of Ethiopia. https://hdl.handle.net/20.500.11766/4731

Gashaw T, Bantider A, Silassie HG. 2014. Land degradation in Ethiopia: causes, impacts and rehabilitation techniques. Journal of Environmental Earth Science, 4(9): 98-104.

Getachew D. 2016. Analysis of preference for adoption of legume technology packages: the case of chickpea and common bean producing smallholder farmers in Boricha and Damot Gale district, Southern region. M.Sc. Thesis. Haramaya University, Haramaya, Ethiopia.

Getachew T. 2019. Pulse Crops Production Opportunities, Challenges and Its Value Chain in Ethiopia: A Review Article. Journal of Environment and Earth Science, 9: 1. DOI: 10.7176/JEES

Habte E, Alemu D, Amsalu B, Yirga C. 2018. Production and Marketing of Major Lowland Pulses in Ethiopia: Review of Developments, Trends and Prospects. Ethiop. J. Crop Sci., Special Issue. 6(3): 435-465.

Habtewold TM. 2018. Adoption and Impact of Improved Agricultural Technologies on Rural Poverty. In: Heshmati A., Yoon H. (eds) Economic Growth and Development in Ethiopia. Perspectives on Development in the Middle East and North Africa (MENA) Region. Springer, Singapore. https://doi.org/10.1007/978-981-10-8126-2_2

Hailu BK, Abrha BK, Weldegiorgis KA. 2014. Adoption and Impact of Agricultural Technologies on Farm Income: Evidence from Southern Tigray, Northern Ethiopia. International Journal of Food and Agricultural Economics, 2(4): 91-106.

IFPRI (International Food Policy Research Institute). 2011. Food and Agriculture in Ethiopia: Progress and policy challenges. https://doi.org/10.2499/9780812245295

ITC (International Trade Centre). 2019. Pulses Sector Investment Profile, Ethiopia. http://www.intracen.org/uploadedFiles/ intracenorg/Content/Redesign/Projects/SITA/SITA_Ethiopia _Pulses_booklet_final_web_page.pdf 
Kamanga B, Kanyama-Phiri GY, Snapp SS. 2001. Experiences with Farmer Participatory Mother-Baby Trials and Watershed Management Improve Soil Fertility Options in Malawi. Harare: CIMMYT.

Kassa B, Alemu D. 2017. Agricultural Research and Extension Linkages: Challenges and Intervention Options. Eth. J. Agric. Sci., 27(1): 55-76.

Kassie M. 2011. Economic and Environmental Benefit of Forage Legume-Cereal Intercropping in The Mixed Farming Systems: A Case Study in The West Gojjam, Ethiopia. Addis Ababa, Ethiopia: Ethiopian Development Research Institute (EDRI).

Kebede E. 2020. Grain legumes production and productivity in Ethiopian smallholder agricultural system, contribution to livelihoods and the way forward. Cogent Food \& Agriculture 6(1): https://doi.org/10.1080/23311932.2020.1722353

Kerr B, Snapp S, Shumba L, Msachi R. 2007. Participatory research on legume diversification with Malawian smallholder farmers for improved human nutrition and soil fertility. Experimental Agriculture 43(4): 437-453. https://doi.org/10.1017/S0014479707005339

Koroma S, Molina PB, Woolfrey S, Rampa F, You N. 2016. Promoting regional trade in pulses in the Horn of Africa. Accra, Ghana, FAO.

Melesse B. 2018. A Review on Factors Affecting Adoption of Agricultural New Technologies in Ethiopia. J Agri Sci Food Res 9: 226.

Meselu YK. 2019. A review on the seed sector of Ethiopia: prospects and challenges of faba bean seed supply. South Asian Journal of Development Research, 1(1): 44-54. http://aiipub.com/journals/sajdr-190514-021007/

MoA (Ministry of Agriculture). 2013. Data on demand and supply of improved seed of different crops. Addis Ababa, Ethiopia.

Mtambanengwe F, Mapfumo P. 2009. Combating food insecurity on sandy soils in Zimbabwe: the legume challenge. Symbiosis, 48: 25-36. https://doi.org/10.1007/BF03179982

Muoni T, Barnes A, Öborn I, Watson C, Bergkvist G, Shiluli M, Duncan A. 2019. Farmer perceptions of legumes and their functions in smallholder farming systems in East Africa. International Journal of Agricultural Sustainability, 17: 205 218. https://doi.org/10.1080/14735903.2019.1609166

Odame H, Kimenye L, Kabutha C, Alemu, D Oduori, LH. 2013. Why the low adoption of agricultural technologies in Eastern and Central Africa? ASARECA (Association for Strengthening Agricultural Research in Eastern and Central Africa), Entebbe. http://dx.doi.org/10.13140/RG.2.2.22249.70244

Popoola J, Ojuederie O, Omonhinmin C, Adegbite A. 2019. Neglected and Underutilized Legume Crops: Improvement and Future Prospects [Online First]. IntechOpen, DOI: 10.5772/intechopen.87069.

Ronner E, Giller KE. 2012. Background information on agronomy, farming systems and ongoing projects on grain legumes in Ethiopia. www.N2Africa.org, 33 pp.

Sanchez PA, Denning GL, Nziguheba G. 2009 The African green revolution moves forward. Food Security 1(1): 37-44. https://doi.org/10.1007/s12571-009-0011-5

Schneider K, Anderson L. 2010. Yield Gap and Productivity Potential in Ethiopian Agriculture: Staple Grains and Pulses; Prepared for the Farmer Productivity Team of the Bill \& Melinda Gates Foundation, Evans School Policy Analysis and Research (EPAR), Brief No. 98.

Shiferaw B, Jones R, Silim S, Teklewold H, Gwata E. 2007. Analysis of production costs, market opportunities and competitiveness of Desi and Kabuli chickpea in Ethiopia. Improving Productivity and Market Success (IPMS). Working Paper, 3. ILRI, Addis Ababa, Ethiopia. https://hdl.handle.net/10568/503
Shiferaw B, Teklewold H. 2007. Structure functioning of chickpea markets: evidence based on analysis of value chains linking smallholders and markets, Working Paper 6, International Livestock Research Institute (ILRI), Nairobi, Kenya.

Tafese TA. 2018. Agricultural Technology Adoption, Commercialization and Food Security Linkage: Micro Evidence from Boricha Wereda, Sidama Zone, Ethiopia. M.Sc. Thesis. Addis Ababa University, Addis Ababa, Ethiopia.

Tegegne Y. 2017. Factors Affecting Adoption of Legume Technologies and its Impact on Income of Farmers: The Case of Sinana and Ginir Woredas of Bale Zone. M.Sc. Thesis. Haramaya University, Haramaya, Ethiopia.

Teshale A, Rubyogo JC, Sperling L, Amsalu B, Abate T, Deressa A, Reda F, Kirkby RR, Buruchara R. 2006. Creating partnerships for enhanced impact; bean variety delivery in Ethiopia. Journal of Crop Science Society of Ethiopia, 12: 27-30.

Tsegaye G, Regassa N, Carol H, Idemudia P. 2015. Smallholder farmers pulse production and marketing of Ethiopia: a gender analysis of access and control of key resources in four districts Humboldt International Journal of Gender, Agriculture and Development, 90-109.

Tsegaye M, Bekele H. 2012. Impacts of Adoption of Improved Wheat Technologies on Households' Food Consumption in Southeastern Ethiopia. Selected Poster prepared for presentation at the International Association of Agricultural Economists (IAAE) Triennial Conference, Foz do Iguaçu, Brazil, 18-24.

UNPF (United Nations Population Fund). 2017. National accounts, UN Population Fund, UNDP data, FAOSTAT and OECD. Conversions done using World Bank annual data on currency conversion factors.

van den Broek J, Sertse Y, Becx G, Asrat P, Beyene T, Dilnesaw Z, Ewnetu Y, Getachew Y, Getahun A, Getaw H, Michael A, Mulugeta M, Shiferaw M, Somano W, Tefera B, Tefera E, Teshome K. 2014. Legume Value-Chains in Ethiopia Landscaping Study. Prepared by Resilience and Shayashone, on behalf of the Bill \& Melinda Gates Foundation.

van Loon, MP, Deng N, Grassini P, Edreira JIR, Wolde-meskel E, Baijukya F, Marrou H, van Ittersum MK. 2018. Prospect for increasing grain legume crop production in East Africa. European Journal of Agronomy, 101: 140-148. https://doi.org/10.1016/j.eja.2018.09.004

Vidigal P, Romeiras MM, Monteiro F. 2019. Crops Diversification and the Role of Orphan Legumes to Improve the Sub-Saharan Africa Farming Systems [Online First], IntechOpen. DOI: 10.5772/intechopen.88076.

Yirga C, Alemu D. 2016. Adoption of crop technologies among Smallholder Farmers in Ethiopia: Implications for Research and Development. Eth. J. Agric. Sci., EIAR 50th Year Jubilee Anniversary Special Issue: 1-16.

Yirga C, Rashid S, Behute B, Lemma S. 2010. Pulses Value Chain Potential in Ethiopia: Constraints and opportunities for enhancing exports. International Food Policy Research Institute pp. 1-53. DOI: 10.13140/RG.2.1.3968.0722

Yirga C, Yigezu A, Aw-Hassan A. 2015. Tracking Adoption and Diffusion of Improved Chickpea Varieties: Comparison of Approaches. Research Report 107. EIAR, Addis Ababa, Ethiopia. http://hdl.handle.net/123456789/2576

Zeng D, Alwang J, Norton GW, Shiferaw B, Jaleta M, Yirga C. 2017. Agricultural technology adoption and child nutrition enhancement: Improved maize varieties in rural Ethiopia. Agric. Econ., 48(5): 573- 586. https://doi.org/10.1111/ agec. 12358 